FACTA UNIVERSITATIS

Series: Linguistics and Literature Vol. 18, No 1, 2020, pp. 19-26

https://doi.org/10.22190/FULL2001019J

Review Paper

\title{
KINSHIP TERMINOLOGY IN THE LUŽNICA REGION
}

\author{
UDC 811.163.41'373.232 \\ $811.163 .41^{\prime} 282$
}

\section{Nadežda D. Jović}

University of Niš, Faculty of Philosophy, Serbian Department, Niš, Serbia

\begin{abstract}
The paper offers an analysis of the kinship terminology for the relations by blood or marriage in the Lužnica region compiled in Rečnik govora Lužnice (The Dictionary of the Lužnica Dialect, 2018) by Lj. Cirić. Along with a lexico-semantic analysis of about one hundred lexemes excerpted from the dictionary, some linguistic and etymological notes are also provided. The objective is to demonstrate that in collecting dialect-specific lexemes systematic lexical Rečnik govora Lužnice inventorying using questionnaires enables an almost perfect reconstruction of the particular terminological system of a dialect.
\end{abstract}

Key words: Rečnik govora Lužnice, kinship, terminology, lexico-semantic analysis

\section{INTRODUCTION}

In this paper, the terminological system of the kinship lexis of the Lužnica region will be presented, with reference to Rečnik govora Lužnice (The Dictionary of the Lužnica Dialect, 2018) by Ljubisav Ćirić. The terminology analyzed refers to relationships based on ties of blood (consanguineal kinship) or ties of marriage (affinal kinship). These two types of relationships are intertwined because blood relations multiply through marriage. The main aim of the paper is not just to present the above-mentioned terminological system of the Lužnica dialect, but also to emphasize the fact that the use of questionnaires in inventorying dialect-specific lexemes supports a complete reconstruction of the terminological system based on the material from a dialect dictionary.

The study of kinship terminology in the Slavic and South Slavic regions so far is not negligible (Bjeletić 1994, 206) and it suggests that kinship terminology is preserved through the preservation of traditional kinship relations (Bjeletić 1994, 199; Petrović-Savić 2011, 181). Considering the fact that this terminology system is one of the key indicators of the social and spiritual code (Nedeljkov 2012, 109-111), it was included in Upitnik za

Submitted May 29, 2020; Accepted June 5, 2020

Corresponding author: Nadežda Jović

University of Niš, Faculty of Philosophy

E-mail: nadezda.jovic@filfak.ni.ac.rs 
srpskohrvatski/ hrvatsko srpski dijalektološki atlas (The Questionnaire for the SerboCroatian / Croato-Serbian Dialectological Atlas). In addition to nominal terms, terms of address were noted (Bjeletić 1994, 200; Dunjić 1996, 316; Petrović-Savić 2011, 187-188); therefore, they will also be discussed in this paper whenever they occur in The Dictionary of the Lužnica Dialect.

Lužnica is a region in southeastern Serbia which belongs to the Timok-Lužnica dialect. However, since it is fragmented, according to the distribution of its linguistic features, it is divided into Gornja (Upper) and Donja (Lower) Lužnica (GL, DL) - with Lužnica linguistic features, and Lužnica-Zaplanje (LZ), where the Lužnica dialect features are mixed with the Zaplanje dialect features (Ćirić 2018, 6-7). Thus, Timok-Lužnica palatalization is used in Gornja and Donja Lužnica, but not in Lužnica-Zaplanje, which is seen in the phonetic differences in certain terms, which appear as lexical variants in The Dictionary (e.g.: мајка / мајћа, маћа, ујка / ујћа, ућа, си́нке / сúнће, снајка / снајћа, еtc.).

In the Introduction to The Dictionary, the author emphasizes that the lexemes were recorded not just in casual conversation, for the purposes of writing a master's thesis (Ćirić 2013), but also using Upitnik za srpskohrvatski/ hrvatsko srpski dijalektološki atlas (The Questionnaire for the Serbo-Croatian/ Croato-Serbian Dialectological Atlas), and a questionnaire designed for collecting various thematic vocabulary items (home and household items, "слава" and wedding customs, food and drink, hunting and fishing, farming, etc.). Also, the lexemes were collected from literary works written in the Lužnica dialect (Ćirić 2018, 6). The use of various questionnaires for collecting lexemes suggests systematicity in inventorying particular sets of thematic vocabulary. On the other hand, given that The Dictionary of the Lužnica Dialect is conceived as a differential dictionary, as opposed to the six-volume Rečnik srpskohrvatskog književnog jezika published by Matica Srpska (RMS), it may not have included the terms which could not be classified as dialexemes by any criteria, whose meanings, however, were well-known (Ćirić 2018, 7-8).

\section{THE KINSHIP TERMINOLOGY}

Kinship terminology which refers to blood relations includes the terms for the family in the narrow and broad senses, spouses - female and male parents, female and male offspring in relation to the parents and each other, the father and mother of each parent in relation to their children, the parents' brothers and sisters in relation to the parents' children, thirddegree (and fourth-degree relatives) relatives, etc. General terms related to relatives include the following lexemes: вами́лија, фами́лија [A NUMBER OF FAMILIES DESCENDED FROM THE SAME ANCESTOR] and pó ${ }^{2}$, родá, своjúнa ${ }^{2}$ [RELATIVES, RELATIONS]. The term podá refers to both male and female blood relationship (consanguinity). Cf. the illustrative material: Моја́ рода́ је голема́ и по ма́терину и по ба́штину стра́ну.

The semantic field which refers to the founders of a family includes the names for spouses (жена, човек / муж) and parents (мајка, башта / татко). The terms that are also included in this semantic field refer to the new spouse of one of the parents in relation to a biological child with the previous spouse (мaћuja, oчyв). [A FEMALE SPOUSE, WIFE] is called жена́, and [A HUSBAND, HOST] is called чове́к, му́ж. The basic meaning of this word is [A GROWN MAN]. [THE ONE WHO GAVE BIRTH TO THOSE SHE GAVE BIRTH TO, MOTHER] is called ма́jка in LZ, мájћa in DL, мáћa voc. мáћo in GL; мámep; мámu voc. нáне; мáмa voc. ма́мо; на́на vос. на́не. The term мáмa is polysemic and refers to kinship based on 
blood and on marriage: мáma [1. HYP. OF MOTHER (USUALLY USED BY CHILDREN). 2. THE OLDEST AUNT IN THE FAMILY COMMUNITY] (see below). The word for [FATHER] is бammá, pl. баште́вu; та́mко, hyp. máma, voc. máme, mámћe [A TERM OF ENDEARMENT FOR A FATHER AND FATHER-IN-LAW] (see heading 3). The lexeme татко́вина is used for [THE INHERITANCE FROM THE FATHER]. According to M. Bjeletić $(1994,204)$ the term бammá was borrowed from Bulgarian. A [STEPMOTHER] is called máћuja in DL, whereas a [STEPFATHER] is óyyb.

Offspring are first-degree relatives to their parents. The general term for [FEMALE OFFSPRING] is же́нска стра́на, and for [MALE OFFSPRING], it is му́шка стра́на (see стра́на). Special terms may be used for children born in wedlock (син, черка), depending on their birth order, the number of children, the death of a parent, etc., in relation to the parents (првенче, истришче), as well as to one another (elder / younger brother, elder / younger sister). [A NEWBORN] is called при́нова, бебе́. [A MALE CHILD, A MALE OFFSPRING] is called му́шко. [A SON, A SONNY] is called синьк, vоc. си́нке in LZ, сúьће in GL, DL hyp. of son. This lexeme (син) is not mentioned in The Dictionary, considering that it is not a dialexeme, except prosodically, but it does occur, for example, in the exemplification of the lexeme óyys: Очув ми је би́л, али је до́бар чове́к би́л, и ко роче́ног си́на чува́л и саве́тувал. [А DAUGHTER] is called че́рка. Special names for offspring with respect to their birth order, twin pregnancy, whether the parent is alive, etc. are: [FIRSTBORN] - прве́нче, прва́ ьче; [THE PARENTS' YOUNGEST CHILD, THE FAVOURITE] - истри́шко, истри́шљак оr истри́шче; [ONE OF THE TWINS (OF EITHER SEX)] - близне́, [A TWIN, ONE OF THE TWIN BROTHERS] - близнáк; [A CHILD WITHOUT PARENTS OR WITHOUT ONE PARENT] - cupoyé; [A CHILD BORN AFTER THE FATHER'S DEATH] - nócMp $y$, [A SON FROM A PREVIOUS MARRIAGE TO THE SPOUSE FROM A NEW MARRIAGE, TO HIS STEPFATHER OR STEPMOTHER] - nácmopa, [A DAUGHTER FROM A PREVIOUS MARRIAGE TO THE SPOUSE FROM A NEW MARRIAGE] - nácmophuњb, [A CHILD FROM A PREVIOUS MARRIAGE TO THE SPOUSE FROM A NEW MARRIAGE] - nácmopye. The 3. person singular verb приведé means [BRINGS A CHILD FROM A PREVIOUS MARRIAGE BY REMARRYING].

The names for the offspring of the same parents or one mutual parent (brother, sister), may have different forms depending on birth order (elder / younger brother; elder / younger sister). [A MALE TO OTHERS BORN TO THE SAME PARENTS OR HAVING ONLY ONE MUTUAL PARENT (FATHER OR MOTHER)] is called бpám or, if it is [A BROTHER BORN TO THE SAME PARENTS], he is called роче́ни бра́m. (See the entry брат.) The lexeme сестра [SISTER] is not mentioned in The Dictionary, but it can be found in the illustrative material in the entries for a number of lexemes. E.g. with dáda, [ELDER SISTER], see: Já u даньc, áко сам cmápa женá, nócmapoza брáma óкам бáme, a nócmapy cecmpý dáde. [AN OLDER BROTHER TO A YOUNGER BROTHER AND HIS WIFE, I.E. HIS SISTER AND HER HUSBAND] is called бáma, hyp. бámка (voc. бámћe). In the words бате, даде, сека, the terminology of consanguineal and affinal kinship are intertwined. [AN OLDER SISTER TO A YOUNGER SISTER (also cf. да́да)] is се́ка, да́da, vоc. дáde. The vocative form is given in the illustrative material together with the lexeme dáda. The term céкa is also a bridal name (see heading 3). This distinction is common is Serbian dialects, therefore, the relationship дадa: сестрa is observed in Veliki Krčimir, Bučum and Vranjsko Pomoravlje (Bjeletić 1994, 203).

The terms used for the relationship of the spouses' parents to the spouses' children are баба, деда for second-degree kinship, прабаба, прадеда for third-degree kinship, and парабаба, парадеда for fourth-degree kinship. The terms used for the father's and mother's ancestors are the same, which is common in Serbian-speaking areas (Bjeletić 1994, 201). The 
term used for [THE FATHER'S AND MOTHER'S MOTHER] is either бáбa or a compound lexeme роие́на ба́ба. This is a secondary meaning of the word бáбa. The primary meaning is [AN ELDERLY WOMAN, AN OLD WOMAN]. In affinal kinship terminology, this lexeme means [MOTHER-IN-LAW]. [THE FATHER'S OR MOTHER'S FATHER] is called déda. This is a secondary meaning of the word. The primary meaning is [AN OLD MAN], whereas in affinal kinship terminology, дéda also means [3. FATHER-IN-LAW] (see heading 3). In Lužnica, [THE INHERITANCE FROM A GRANDFATHER] is called деде́вина. [A GRANDMOTHER'S OR GRANDFATHER'S MOTHER] is called пра́бабa or пре́баба. The name for [A GRANDMOTHER'S OR GRANDFATHER'S FATHER] cannot be found in The Dictionary, however, it can be assumed, with a high degree of certainty, that it is analogous to пра́баба, пре́баба, and is therefore nрádeda or nрédeda. [A GRANDFATHER'S OR GRANDMOTHER'S GRANDMOTHER] is called парáбaбa, and [A GRANDFATHER'S OR GRANDMOTHER'S GRANDFATHER] is napádeдa.

To their parents and more distant ancestors the children are grandchildren, and no distinction is made in terms of whether they are the children of a son or daughter, as is usually the case in the Serbian language (Bjeletic 1994, 201). The terms for the male and female descendants in relation to the spouses' parents, унук and унука, are not inventoried as dialexemes, but are mentioned in the illustrative material with the lexeme yнýuе [DIM. OF GRANDCHILD]: Имамо три́ уни́чета, уну́ка и две́ уни́ће. The definitions and forms of the terms used for descendants in the third and fourth degrees of kinship are analogous to the terms for ancestors in the third (пра́баба / пре́баба) and fourth degrees of kinship (пара́баба, пара́деда): [A GRANDSON'S OR GRANDDAUGHTER'S CHILD] is called пра́унуче and пре́унуче; [A GRANDSON'S OR GRANDDAUGHTER'S SON] is called пра́унук and пре́унук; [A GRANDSON'S OR GRANDDAUGHTER'S GRANDDAUGHTER] is called пара́унука, [A GRANDSON'S OR GRANDDAUGHTER'S GRANDSON] is called пара́yнук.

As in the majority of Serbian dialects (Bjeletić 1994, 202), different names are used for the mother's or father's brother or sister in relation to the parent's children, depending on the line of kinship: the male line (старко / чича, тетка) or the female line (ујка, тетка), but also on whether the uncle, as a prominent figure in the patriarchy, is older or younger than the father. The lexeme used for [AN UNCLE IN RELATION TO HIS YOUNGER BROTHER'S CHILDREN] is either cmápкo or a compound lexeme cmápu бammá (see бammá), voc. cmápu máme, ста́рко. [AN UNCLE YOUNGER THAN THE FATHER] is called чúчa. The secondary meaning of this word is [ANY ELDERLY MAN]. [AN UNCLE'S WIFE, THE WIFE OF THE FATHER'S BROTHER] is called стри́на, voc. стри́но. The secondary meaning of this word is [A FORM OF ADDRESS FOR ANY OLDER WOMAN], (cf. cmpúu). In the illustrative

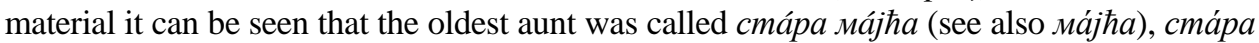
ма́мa ${ }^{1}$ vос. ста́pa мájћe, мáмо, cf. the exemplification of the term стри́на 1: Некадá je нájстара стри́на била́ ста́ра мájће, и сва́ деца́ су ју ока́ла „ста́ра ма́мо“, а дру́ђе су би́ле стриине, и ока́ле се „стри́но“. [AN UNCLE] is called ýjкa in LZ, ýjћa in DL, ýћa in GL. The term for an uncle's wife is not listed in The Dictionary, but it can be assumed that it is not a dialexeme, except in prosodic terms, and that it is yjнa. [THE FATHER'S OR MOTHER'S SISTER] is called mémкa. The secondary meaning of this lexeme is [A FORM OF ADDRESS FOR ANY ELDERLY WOMAN]. [THE AUNT'S HUSBAND, UNCLE], who is not related through blood to the children of the spouse of the family founder, is called тетú names for the children of a brother or sister of one of the spouses of the family founder

${ }^{1}$ [THE OLDEST AUNT IN THE FAMILY COMMUNITY] is observed as a secondary meaning of the lexeme $м a ́ m a$, while, in the illustrative material, it can be seen that it is a compound lexeme cmápa мáma, voc. cmápa мáмo. 
differ depending on the sex of the relatives (brother / sister and son / daughter), which is in accordance with the situation in a wider Serbian-speaking area (Bjeletic 1994, 202): [A BROTHER'S SON, NEPHEW] is called бpámaнau, [A BROTHER'S DAUGHTER, NIECE] is бра́таница; [A SISTER's SON, NEPHEW] is called cecmpúчuч, [A SISTER'S DAUGHTER, NIECE] is called сестри́чина in GL, DL, сестрична in LZ.

In Lužnica, kinship based on vows is denoted by the lexemes nобрámuм, [THE FRIEND CHOSEN BY HIS FRIEND AS A BROTHER, OR USED ONLY IN COURTEOUS ADDRESS] and nосе́стрима, [ANY FEMALE WHO IS RESPECTED AS A SISTER]. [FRATERNIZE IN THIS WAY (3. person singular)] is said брати́ми се, побрати́ми се. The vocative form бра́тми, [MY BROTHER], has the same root.

\section{MARRIAGE RELATIONS}

When a couple gets married (венча се or венчуjе ce), each of the spouses [BECOMES RELATED BY MARRIAGE] - opódu ce. These terms are part of the lexicon of wedding customs (Petrović-Savić 2009, 81-82; Jović 2020), but also of the lexicon of family relations (Dunjić 1996, 320-322; Petrović-Savić 2011, 182-185). The lexicon of wedding customs includes terms which denote different roles at a wedding, thus they can have a temporary nature: e.g. [THE BRIDEGROOM AND BRIDE DURING THE WEDDING CEREMONY] - младе́нции, [MAN ON HIS WEDDING DAY] - младоже́ґ $а$, [BRIDE UNDER THE VEIL DURING THE WEDDING CEREMONY] - мла́да неве́ста (see неве́ста), which is a compound lexeme, consisting of the sememe [GIRL WHO SOMEONE INTENDS TO MARRY, FUTURE WIFE] - мла́дa and неве́ста [daughter-in-law in the first year of marriage]. The names of some of the prominent participants in a wedding ceremony, e.g. кýм, куми́ца; старо́jко in LZ, старо́jћa in GL and DL, ста́ри свám, старосватици, strictly speaking, do not belong to kinship terminology, although the one of two godfathers (cmápu cвám) had to be the bridegroom's relative, usually his uncle.

Since the parents of the newlyweds played an important role in the traditional marriage, the terms used for the newlyweds' parents are included in this semantic field. [THE FATHER OF ONE SPOUSE IN RELATION TO THE FATHER OF THE OTHER SPOUSE] is called npújemes, whereas [THE MOTHER OF ONE OF THE SPOUSES IN RELATION TO THE PARENTS OF THE OTHER SPOUSE] is пријетељи́u̧a. The verbs пријете́љи се, опријете́љи ce, cnpujemés u ce mean [BECOME RELATED TO SOMEONE BY THE CHILDREN'S MARRIAGE (3. p.sg.)]. The more general terms for relatives by marriage are: $c в a ́ m^{2}-$ [A MALE RELATIVE BY MARRIAGE] and crája - [A FEMALE RELATIVE BY MARRIAGE].

The key kinship relationships based on marriage are established between the newlyweds and their families. The most important person in these relationships is the new member of the family who is, as a rule, the bride. [THE DAUGHTER-IN-LAW, THE SON'S WIFE] is called cнájкa in LZ, chajћa in DL, chaa in GL, with [THE DAUGHTER-INLAW IN THE FIRST YEAR OF MARRIAGE] being called невécma. The secondary nonterminological meaning of this lexeme is [A YOUNGER WOMAN IN GENERAL], while the expressive, derogatory meaning is [A GROWN ALTHOUGH STILL CHILDISH YOUNG WOMAN]. [THE DAUGHTER'S OR SISTER'S HUSBAND] is called sém. [THE HUSBAND WHO CAME TO THE WIFE'S HOUSE] is called дозе́так and призе́тко.

The parents of the newlyweds on the bridegroom's side are: [THE HUSBAND'S FATHER, THE FATHER-IN-LAW], who is called све́кьp, све́кp, máma, voc. máme and [THE 
HUSBAND'S MOTHER], who is called свекр'ва (see свекр'ва ${ }^{1}$ ). The term máme is a [TERM OF ENDEARMENT FOR THE FATHER AND FATHER-IN-LAW] (see heading 2). In the Lužnica dialect there is a homonym meaning [A WOMAN WHO COOKS AT WEDDINGS], found in the terminology of wedding customs (see свекрв $a^{2}$ ). For the groom, the bride's parents are [FATHER-IN-LAW] - дéda, and [MOTHER-IN-LAW] - бáбa. For the other meanings of this lexeme see heading 2 . In the terminology of kinship based on blood, the term déda also means [THE FATHER'S OR MOTHER'S FATHER] (see heading 2).

Some of the terms used for the newlyweds' brothers and sisters and their spouses are of foreign, Turkish origin (балгъза, бáua). Cf. Škaljić 1989, bàlduza [THE WIFE’S SISTER, SISTER-IN-LAW] < Tur. bald $z ;$ badžànak, badžènok... [THE HUSBAND OF THE WIFE'S SISTER (IN RELATION TO THE OTHER SISTER'S HUSBAND)...] < Tur. bacanak. [THE HUSBAND'S SISTER, SISTER-IN-LAW] is the bride's зь'лва, whereas in The Dictionary there is no information about the term used for the husband of the husband's sister in relation to the bride. $^{2}$ The lexeme which means [THE HUSBAND'S BROTHER, BROTHER-IN-LAW] is not inventoried in The Dictionary, but the form де́вер is confirmed in the illustrative material with the lexeme nродása [2. THE PART OF THE WEDDING RITUAL WHEN THE BRIDE'S BROTHER RITUALLY SELLS HIS SISTER TO HER FUTURE BROTHER-IN-LAW]. The same conclusion can be drawn from the derivatives девери́чич, девериччина (see below). A similar deduction can be made about the sememe [THE WIFE OF THE HUSBAND'S BROTHER, SISTER-IN-LAW], which, based on the derivatives jетрви́чина (see below) and jетрве́тина [PEJ. OF THE WIFE OF THE HUSBAND'S BROTHER], would read jemṕsa in the Lužnica dialect. In Lužnica, [THE WIFE'S SISTER IN RELATION TO THE WIFE'S HUSBAND] is балгъ́з бългъз $а$, свасти́ка, whereas [THE WIFE's SISTER'S HUSBAND, SISTER-IN-LAW'S HUSBAND] is called бáua, бацана́к. The secondary meaning of the lexeme бáua is [THE LOVERS OF THE SAME WOMAN]. The sememe [THE WIFE'S BROTHER] and the lexeme uypák are not mentioned in The Dictionary, but can be found in the illustrative material for the lexeme иурња́ja [THE WIFE OF THE WIFE'S BROTHER]. Cf.: Во́лим да ми до́jде шура́к, али по́више во́лим да до́jде иурьъ́jа. For the children of her husband's brothers and sisters, the bride uses derivatives of the above-mentioned names for the groom's brother and sister: [THE HUSBAND'S SISTER'S SON] is called зь'лвичич, [THE HUSBAND'S BROTHER'S SON] is called девери́чич, [THE HUSBAND'S BROTHER'S DAUGHTER] is девери́чина, which is the same as [THE DAUGHTER OF THE HUSBAND'S BROTHER'S WIFE] - jeтрви́чина.

In Lužnica, too, it is customary for the bride, who comes to a new home, to give the socalled bridal names to the younger members of her husband's family. This custom had a preventive character and was widespread among the South Slavs (Sikimić 1998, 29-30). Under the entry for name, The Dictionary mentions 36 female and 16 male bridal names, all of which have a positive connotation, and can be classified into several semantic groups which are mostly magical-symbolic in character (Bjeletić 1996: 97-99). ${ }^{3}$ Most often, female names are inspired by the names of plants or parts of plants: Божу́рка, Вилда́нка, Врби́йа, Ја́бука, Ја́года, Ло́зийа, Мали́на, Пловди́на, Транда́вилка, Ћи́тицุа, Шамшиикка. M. Bjeletić $(1996,98)$ makes the same conclusion based on more extensive material, observing that plant names are used exclusively for women, as well as that they

\footnotetext{
${ }^{2}$ In the Željin Župa region (Dunjić 1996, 321) he is зem to the bride as well as to her husband.

${ }^{3}$ Cf. Sikimić 1998, 32-33 and the list of bridal names from a wider Serbian-speaking area, as well as Dunjić 1996, 322 and the data collected in the Željin Župa region, and Petrović-Savić 2009, 84 and the data from Radjevina.
} 
are the names of those plants that have special symbolism in folk tradition. Some female bridal names are inspired by the names of toponyms: Београ́mка, Вароша́нка, Ду́навка, Мора́вка, Студе́нка, Шумади́нка; bird names: Голуби́ца, Гр́лииза оr Гр́личка, Гугу́тка, Је́ребица; kinship terminology: Се́ja, Се́ка, Сестри́щ̧а [THE BRIDAL NAME THAT, UPON COMING TO THE NEW HOME, THE BRIDE GIVES TO HER HUSBAND'S YOUNGER SISTER (cf. also Сека)], and, in general, the names with various positive associations: Вр́вурка (врвуран [DILIGENT, FAST]), Големи́ц̧а, Дука́тка, Краљи́ц̧а, Ла́лка, ${ }^{4}$ Левте́рка (ле́втеран [SUITABLE FOR HANDLING, EASY TO USE, WHICH FITS NICELY IN THE HAND]), Пúcapкa [THE BRIDAL NAME GIVEN TO THE HUSBAND'S BROTHER'S OR HUSBAND'S SISTER'S OLDER DAUGHTER], Пра́nорка, Таврали́ја, Таврали́ка [FOLLOWING THE LATEST FASHION TRENDS, BEING VERY/TOO STYLISH, ADORNMENT], Убавúųa. Male bridal names are usually inspired by the names of desirable occupations or titles: Вези́p, Војво́да, Овиийр, Пи́сар; kinship names: Ба́jћа, Ба́jча, Бра́ца; bird names: Го́луб, Славе́јко, Со́кол, or they have other positive connotations: Дáca, Дели́ja [A HEALTHY AND ATTRACTIVE PERSON], Ђuдúja, Меракли́ја, Таврали́ја, Убаве́нко.

\section{CONCLUSION}

Based on around 80 analyzed terms, which, together with their phonetic and derivational variations, amount to around 100, and the additional 36 female and 16 male bridal names, it can be concluded that Rečnik govora Lužnice proved to be a very exhaustive and useful source of kinship terminology. It is a terminology which, as shown in this paper, in its essence coincides with the terminology used in a wider Serbian-speaking area and the standard Serbian language. A term can be a dialexeme ${ }^{5}$ based on its contents originating in its secondary meaning, which is very common in the Lužnica dialect (Ćirić 2013, 373), but also owing to its derivational morphology, phonetics and prosody. According to the phonological criteria, the dialexemes analyzed in this paper are usually characterized by the

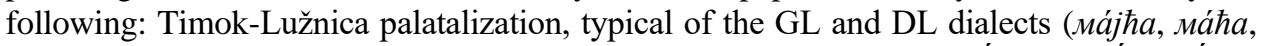
па́сторћиња, сна́jћa, ýjћa, ýћa); the presence of semivowels (балгъза, бългъза, зьлва, зи́лвичич, синьк, све́кьр); the absence of the consonant $h$ (ма́ћија, óчув, сна́a); the substitution of the consonant $f$ (вами́лиja); the consonant $\check{c}$ instead of $\dot{c}<* t j$ (девери́чич, зь́лвичич, че́рка); and also $d \check{z}<* d j$ (роче́ни бра́m, роче́на ба́ба), which are the most striking phonetic features of the Timok-Lužnica dialect.

As only the prosodic criterion was used to determine whether a dialexeme would be included in The Dictionary, certain lexemes, e.g. девер, јетрва, сестра, ујна, унук, унука, цурак, were not included. However, they are present in the illustrative material with other, mostly related lexemes so that they too can be excerpted, through careful reading. Some terms could be reconstructed with great certainty, e.g. пра́деда / пре́деда, уjна, based on inventoried lexemes (пра́баба, пре́баба, ујка), which are their pairs in the system.

A special advantage of the insight into the terminological system of a dialect through a dialect dictionary is in the fact that secondary meanings of lexemes are inventoried in

\footnotetext{
${ }^{4}$ In the Lužnica dialect, ла́ла is [THE NAME OF A PLANT], whereas лáлe is both [THE NAME OF A PLANT] and [A TERM OF ENDEARMENT FOR A CHILD]. Other interpretations are possible, e.g. лалка means [OLDER SISTER] in Vranje (Bjeletić 1994: 203).

${ }^{5}$ The author of The Dictionary defines this term as a lexeme which is formally and semantically marked compared to a standard lexeme (Ćirić 2013: 371).
} 
the dictionary, but are usually not obtained through collecting vocabulary using a questionnaire. In that sense, dictionaries provide wider possibilities for the study of thematic vocabulary, which is particularly true for The Dictionary of the Lužnica Dialect, which, due to its underlying idea and scope, as well as a wide exemplification of entries, provides possibilities for linguistic and other research.

\section{RESOURCE}

Ćirić, Ljubisav. 2018. “Rečnik govora Lužnice.” Srpski dijalektološki zbornik LXV/2: 5-1166.

\section{REFERENCES}

Bjeletić, Marta. 1994. “Terminologija krvnog srodstva u srpskohrvatskom jeziku.” Južnoslovenski filolog L: 199-207.

Bjeletić, Marta. 1996. “Od devet brata krv.” Kodovi slovenskih kultura 1, Biljke: 89-101.

Dunjić, Olivera. 1996. "Termin za svojtu u Željinskoj župi.” Srpski jezik, studije srpske i slovenske 1/1-2, godina I: $316-323$

Jović, Nadežda. 2020. "Dijalekatski rečnik kao slika narodnih običaja (na primeru Rečnika govora Lužnice Ljubisava Ćirića)." U Običaji и kulturi Srba i Bugara / Обичаите в културата на сърби и българи (u štampi). Niš: Filozofski fakultet.

Nedeljkov, Ljiljana. 2012. "Tematska leksikografija kao svedočanstvo o kulturnom identitetu.” U Filologija $i$ univerzitet, ur. Bojana Dimitrijević, 105-120. Niš: Filozofski fakultet.

Petrović-Savić, Mirjana. 2009. Leksika svadbenih običaja u Rađevini. Beograd : Institut za srpski jezik SANU.

Petrović-Savić, Mirjana. 2011. "Terminologija rodbinskih odnosa nastalih sklapanjem braka (oblast Rađevina)." U Dijalekat - dijalekatska književnost, ur. Radmila Žugić, 181-189. Leskovac : Leksovački kulturni centar.

RMS. 1967-1976. Rečnik srpskohrvatskog književnog jezika, I-III. Novi Sad - Zagreb : Matica srpska - Matica Hrvatska, 1967-1969; Rečnik srpskohrvatskog književnog jezika, IV-VI. Novi Sad : Matica srpska, 19711976.

Sikimić, Biljana. 1998. "Nevestinska imena: od hipokoristika do pejorativa." Srpski jezik, studije srpske $i$ slovenske, 3/1-2, godina III: 29-55.

Ćirić, Ljubisav. 1983. “Govor Lužnice.” Srpski dijalektološki zbornik XXIX: 7-190.

Ćirić, Ljubisav. 2013. "Obim diferencijacije i mera egzemplifikacije u dijalekatskim rečnicima." U Putevi $i$ dometi dijalekatske leksikografije, ur. Jordana Marković, 369-376. Niš: Filozofski fakultet.

Škaljić, Abdulah. 1989. Turcizmi u srpskohrvatskom jeziku. Sarajevo: Svjetlost.

\section{TERMINOLOGIJA RODBINSKIH ODNOSA U LUŽNIČKOM KRAJU}

U radu je na materijalu Rečnika govora Lužnice (2018) Lj. Ćirića, odakle je ekscerpirano oko 100 leksema, predstavljena terminologija rodbinskih odnosa na osnovu krvnog srodstva i na osnovu braka u lužničkom kraju. Izvršena je leksičko-semantička analiza uz koju su date jezičke i etimološke napomene. Cilj je bio pokazati da sistematsko popisivanje leksike pomoću upitnika prilikom prikupljanja dijalekatske leksike omogućava veoma potpunu rekonstrukciju određenog terminološkog sistema jednog govora.

Ključne reči: Rečnik govora Lužnice, rodbinski odnosi, terminologija, leksičko-semantička analiza 